\title{
Grip and the Bengoughs as Publishers and Printers
}

\section{Carl Spadoni}

In her autobiography, The Side Door, Dora Hood refers to a customer who visited her antiquarian bookstore in 1939 and wanted to purchase copies of the Canadian satirical magazine, Grip. Although Mrs. Hood had gathered together a bundle of issues, she explained to the customer that it would be difficult to collate a complete run. 'I know,' replied the man, 'for I am the last surviving brother of the five Bengoughs, and I am over ninety.' Before he left the bookstore, he jotted down a summary of Grip and its associated publishing companies:

Grip (Weekly Paper)

J.W. Bengough, ed. and artist.

T. Bengough, printer.

May 24, I873, to Dec. 29, I894.

I 875 G. Bengough came in.

Called Bengough Bros.

I88I J.W. Bengough, S.J. Moore \& G. Bengough.

I 883 Grip Printing Publishing Co.

Ran paper until July, I893.

Then suspended at Ser. No. I048.

I 894 Jan. 4 - Ist No. of N.S. (whole ro49).

Phoenix Publishing Co. (J.W. Bengough, J.J. Bell)

8I Adelaide St. West.

Ran until I894. Dec. ${ }^{1}$

Mrs. Hood's customer was Thomas Bengough (I 853-1945) who can be forgiven for exaggerating his age, since he was eighty-five or eighty-six in I939. He must have had a very active life. Besides being a printer, he had been among other things a newspaper journalist, an official reporter for the

This paper was given at the $43 \mathrm{~d}$ Annual Meeting of the Bibliographical Society of Canada held at the University of Windsor, Windsor, Ontario, on 3 I May 1988. 
York County Courts, private secretary to Sir Oliver Mowat, reporter to the Canadian Senate, editor and publisher of two religious periodicals, and proprietor of Bengough's Shorthand and Business Institute. ${ }^{2} \mathrm{He}$ was also the brother and literary executor of Canada's greatest political cartoonist of the period, John Wilson Bengough (I85I-I923). ${ }^{3}$

J.W. Bengough's career spans half a century, from the first government of Sir John A. Macdonald in Victorian Canada to the reconstructionist era following the First World War and the rise of William Lyon Mackenzie King. Bengough was more than just a cartoonist, although in this capacity his influence was enormous. His writings and caricatures appeared in a variety of journals and dailies such as the Toronto Globe, the Montreal Star, the Morning Chronicle (London), the Public (Chicago), the Farmer's Advocate (London, Ont.), the Varsity, and Review of Reviews. Printer, editor, journalist, poet, humorist, lecturer, teacher of elocution, and minor politician, he was a moral crusader, an advocate of free trade and women's suffrage, an ardent prohibitionist, and a champion of the single tax. His 'chalk-talks,' during which he drew caricatures of prominent citizens and spoke engagingly about 'the pleasantries of public life,' entertained audiences in Canada, the United States, Great Britain, New Zealand, and Australia. ${ }^{4}$ It was in the pages of Grip, however, that he first established his enduring reputation.

This essay will focus on the publishing history of Grip and the publishing firms associated with it, from the founding of the magazine by Bengough in 1873 to its closing in I894. In spite of the fact that the records of these firms are not extant, the story can be reconstructed from Grip itself, from Bengough's papers, and from various documents of the time. Throughout this essay the name 'Bengough' without qualification is used to refer to J.W. Bengough rather than to any of his brothers.

Born in Toronto but raised in Whitby, Bengough was one of six children, the others being George, Thomas, May, James, and William. ${ }^{5}$ At one time or another all the brothers were employed in some capacity related to publishing. Their father, John Bengough, who was 'an expert cabinet maker and stair builder,' assisted in the construction of Whitby's Trafalgar Castle, the grandiose residence of Sheriff Nelson Gilbert Reynolds, later occupied by the Ontario Ladies' College. ${ }^{6}$ Scottish on the father's side and Irish on the mother's, the family was Unitarian according to the I87I census. A strong believer in Christian principles, Bengough espoused the liberal concepts of religious toleration and the separation of church and state. He was described later in life as 'a Presbyt., who feels equally at home with all churches. $^{\prime 7}$

Bengough's career as a student was academically undistinguished. He received an award for general proficiency, but by his own admission this 
was due more to the liberal standards of the examiners than to his aptitude or diligence. ${ }^{8}$ In his early teens he developed a fondness for pencil drawing. After his school days he 'flopped about considerably,' first as a photographer's assistant and then as a legal clerk, ${ }^{9}$ but neither of these occupations held his interest for long. Bengough's first real job was as a printer for the Whitby Gazette, owned by George H. Ham; his younger brother Thomas was similarly employed there a few years later. ${ }^{10}$

According to Thomas's recollection, 'the smell of printer's ink appealed to every fibre in the personality of our young hero, and the click of movable types as he placed them in the composing stick was music to his ears. ${ }^{11}$ While there can be no doubt that Bengough preferred being a printer at the Whitby Gazette to being employed in his former positions, he was scarcely enamoured of the routine tasks of the printer's life. He had editorial aspirations, and he 'regarded the mechanical department as the mere vestibule to the career' that lay ahead. His 'immediate services appertained to the composing room and consisted in the setting of type, and one particular night of each week, performing the same function around the Washington handpress in the getting out of the paper. ${ }^{12}$ At the Gazette during the dinner break, he would often draw or write 'poetry for the good of humanity.' Invariably the press foreman would sternly call him back to 'sticking type,' leaving Bengough frustrated and his sketches and poetry frequently unfinished. The only opportunity Bengough had for his literary pursuits was when he wrote a serial story as a filler item for a four-page bulletin that the Gazette issued with its daily edition during the Franco-Prussian War. ${ }^{13}$ Some fifteen years later in the pages of Grip, there appeared a poem authored by 'Varietas' entitled 'Advice to a Printer /Who Has Been Writing Poetry for the Papers).' It goes as follows:

Beware, my friend. It is not safe

To jingle rhymes, whilst thou

Dost click the types and fondly chafe

Thy chin, with self-pleased bow.

Stick, man, to thy 'composing stick' -

Yet ne'er 'composed a line,'

Keep a peeled eye on 'guiding Nick,'

And this 'brass rule' of mine:

High on thy three-legged stool, sit down

Before the cases twain;

Then 'Follow Copy!' - yea, thou clown

Compose thy heated brain.

Scant 'furniture' adorns thy mind,

More like art thou to groan 
A 'galley'-slave, than, dying, find

Fame's most 'imposing stone. ${ }^{14}$

Although Bengough's job at the Gazette was far from ideal, it enabled him to read magazines and newspapers that arrived on exchange at the Gazette offices. One of these was Harper's Weekly, which contained the work of Thomas Nast, one of the great American cartoonists of the nineteenth century. Nast's cartoons lampooned the graft and corruption of New York City's Tammany Ring. Filled with admiration for Nast's work, Bengough saw at once how caricatures could translate beliefs into graphic statements of moral conviction. With a few imaginative strokes of the artist's pen, political dishonesty and mismanagement could be held up to public contempt and ridicule. Bengough's ambition was to follow in Nast's footsteps, but with a Canadian perspective. Since cartoons were practically non-existent in Canadian newspapers in the early 1870 , his ambition appeared doomed from the outset. Between I 849 and I870 a number of Canadian comic journals such as Punch in Canada, Nonsense, the Tester, the Gridiron, Diogenes, the Sprite, and the Grumbler made their brief appearance. Prior to Bengough, however, the only successful publication in Canada in which cartoons were prominently featured was the Canadian Illustrated News (Montreal) which began on 30 October I 869. ${ }^{15}$

In 1872 Bengough went to Toronto as a reporter for the Globe. At the same time he enrolled in evening classes sponsored by the Ontario Society of Artists. He quit his classes before the end of the first term, however, because he preferred drawing from real life instead of copying the placid countenances of Greek deities in plaster casts. ${ }^{16}$ Nevertheless, he continued sketching in his free time. One of his sketches was of James Beaty, the member of parliament for Toronto East and the proprietor of the Leader,'the old established and atrociously printed organ of the Conservative party.' A friend showed this pencilled portrait to Samuel Beaty, who was the manager of the Leader Newspaper Office. Far from being displeased with the caricature of his uncle, Samuel Beaty took it to the engraving and lithographic business of J.T. Rolph, and the resultant lithograph was returned to Bengough. 'I had not up to that time known anything of the mysteries of lithography,' Bengough wrote in recollection of the episode, 'and the ease and accuracy with which the reproduction was done struck me with amazement.' He drew other political cartoons during this time, which were lithographed and were then sold on the streets. But the lithograph of James Beaty gave him an idea. 'Why not start a weekly comic paper with lithographed cartoons?' It was from this speculation that Grip was first born on Queen Victoria's birthday, 24 May I $873 .{ }^{17}$

The initial issues of Grip were four pages in length and sold for five 
cents a copy or two dollars for a year's subscription. The price doubled a year later for a very short period when the weekly was expanded to eight pages. The original price was reinstated, probably as a result of loss of subscriptions, and remained relatively constant thereafter in spite of the fact that the paper eventually expanded to sixteen pages and often contained coloured cartoons. ${ }^{18}$ The first number incurred a deficit of \$ I7.I8, which was shared by Bengough and Thomas. ${ }^{19}$ Although Thomas acted as the business manager for the first issue, this responsibility, along with the magazine's distribution, was assumed by the wholesale newsdealer, bookseller, and publisher, A.S. Irving. Indeed, an examination of the first several issues of Grip would lead one to the erroneous view that with the exception of the cartoons signed by Bengough, Grip was chiefly a product of Irving's enterprise. When Grip began, Bengough was still employed as a reporter for the Globe and Thomas also worked there as a printer.

The earliest masthead features the word GRIP carved from the branches of a tree with a raven perched on the inside curve of the first letter amid a scene of mischief and folly. Grip was named after the pet raven in Charles Dickens' Barnaby Rudge, a bird about I 20 years old that could speak and entertain and 'acquired a degree of sagacity which rendered him famous for miles round. ${ }^{\prime 20}$ The magazine's first editor was 'Charles P. Hall,' which was probably an editorial mask for Bengough himself. Hall lasted until 26 July I 873 . He was succeeded by 'Jimuel Briggs' (the pen name used by Thomas Phillips Thompson for a series of humorous articles in the Telegraph and Mail), who remained until 6 September I873. ${ }^{21}$ 'Demos Mudge' (a pseudonym of R.H. Larminie of the Toronto Globe) and 'Barnaby Rudge' shared the editorial chair in $\mathrm{I} 874{ }^{22}$ 'Barnaby Rudge' resided as editor up to volume I2, no. I9, 29 March I879, at which point the paper finally announced Bengough's position as editor and illustrator.

Grip's policy was to speak unequivocally on the side of right, to be politically independent of any party but never to be neutral. ${ }^{23}$ In an era when newspapers were still known for political partisanship, Grip presented itself as an impartial judge of Canadian affairs. In a cartoon that appeared in I 883 entitled 'It All Depends Whose Ox Is Gored,' Bengough depicts two dead oxen representing the two parties of the day. One ox makes the accusation 'Grip you're a Tory,' and the other ox replies 'Grip you're a Grit.' In the centre of the cartoon the raven as the editorial mascot counters 'A plague on both your houses. ${ }^{24}$ Whether the magazine was always forthright and objective is questionable. A number of critics have charged that Bengough's sympathies were clearly aligned with Alexander Mackenzie and the Liberals and that he regarded Macdonald and the Tories as the root of all evil. ${ }^{25}$ In the House of Commons Sir Leonard Tilley supposedly 
claimed that the real name of the magazine should be Grit, not Grip. Bengough himself acknowledged:

... Some bias in favor of Liberal principles must have been manifest, because all my own personal instincts were then, as they still are, in a democratic direction. I was not blind to the shortcomings of the Liberal party, however, and took a special pleasure in lampooning Liberals if they gave me a chance. ${ }^{26}$

The magazine contained witticisms, jokes, short stories, fables, satirical poetry, letters, answers to correspondents, commentaries, editorials, reports from newspapers and other publications, advertisements, and of course, cartoons. More than anything else, it was the cartoons that marked Grip as distinctive and appealed to a large readership. Although 'there was no great furore over the initial number, ${ }^{27}$ the magazine's circulation was positively affected by the political controversy known as the Pacific Scandal. ${ }^{28}$ Following the closely contested election of 1872 when the Conservatives were returned to power, allegations of bribery and patronage ensued as a result of the leaking of Madonald's correspondence concerning Sir Hugh Allan, a Montreal businessman who donated a substantial amount of money to the Conservative campaign and then became president of the newly-formed Canadian Pacific Railway Company. Sir John A.'s exaggerated features were easy targets for Bengough's caricatures. In one of the best known of Bengough's cartoons, Macdonald is portrayed in an inebriated state, tramping on a woman's back. The woman is a symbol of Canadian virtue. His arms extended, Macdonald cries out 'These hands are clean!,' the words imputed to him when he was confronted with evidence of corruption in the House of Commons; but in the palm of his left hand is etched 'Send me another \$ Ioooo. ${ }^{29}$

Bengough's cartoons were the talk of the country. 'A big batch of Grips went to Ottawa,' Thomas recalled of the time. 'They were feverishly bought up, and further bundles were called for. The legislators were all agog. ${ }^{30}$ Shortly after the scandal came to light, Grip's circulation reached over 2,000 subscribers. ${ }^{31}$ The cartoons of Grip's first year met with such success that they were re-drawn by Bengough, lithographed, and published in book form. 'Come and see me personally at No. 2 Toronto Street,' he invited his readers, 'where I have hung my basket, and every Saturday croak "Never Say Die" to an increasing circle of patrons. ${ }^{132}$

Initially the company was known simply as J.W. Bengough \& Co., and editorial correspondence was directed to a post office box. The company was a small operation concerned chiefly with the literary and physical production of the magazine. 'He [Grip] gives employment more or less 
permanently to at least two full grown men and one boy,' Bengough reported in August $1873 .{ }^{33}$ Given that Bengough and his brother were both printers, it is more than likely that in the beginning they themselves set all the type and completely printed the magazine, leaving the lithographic work to more capable hands. In the prospectus to volume 3, the Toronto subscription booksellers, Clever \& Rogers, called for agents who would canvass for subscribers. 'The publishers purposely refrained from sending out canvassers up to the present time, as they desired to prove that "Grip" - unlike its many predecessors - would be a permanent institution. ${ }^{34}$

In January 1875 Thomas opened an office at No. 2 Toronto Street in order to manage the business side. In March of the same year another office was opened at 20 Adelaide St. East by Bengough's older brother George, who apparently assumed most of Thomas's responsibilities until I88I. The firm of Bengough Bros., a partnership between George and Bengough, was registered on 8 January $1877 .{ }^{35}$ A few months later the company 'moved to more extensive premises in that very handsome stone edifice created last summer known as the Imperial Buildings [30 Adelaide St. East], one door west of the Post Office. ${ }^{36}$

George's contribution heralded a transition in which the firm became more than just a vehicle for the publication of Grip, but was recognized in Toronto as an important company for printing, engraving, publishing, and related activity. Shortly after George's arrival the firm advertised to do 'PLAIN AND ORNAMENTAL PRINTING' and about a year later job printing of items such as business cards, catalogues, and handbills. ${ }^{37}$ By this time the firm also did lithography and engraving for the public. ${ }^{38}$ In May I 877 Bengough Bros. boasted ownership of nine different styles of type from various American, Canadian and European foundries. In August I 878 it offered its services as designers and engravers for 'humorous sketches ... books, newspapers etc. ${ }^{39}$ The pages of Grip listed 'cheap books' and sundry stationery, all for sale at the Grip office. The firm also acted as agents for American journals such as Scribner's Monthly, St. Nicholas, and the Detroit Free Press. As business manager George's expansion of the interests of Bengough Bros. was so extensive that during I877-78 the firm was even a real estate agency. ${ }^{40}$ When George resigned in I $88 \mathrm{I}$, Bengough gave him full credit for a job well done:

He assumed the management of the paper when it was in its struggling infancy, and stood by it devotedly until it reached its present position of success and prosperity. He now resigns the helm to other hands, and retires from the business connection with the mutual good wishes and good will, not only of his late partner, but, we are sure also of the numerous friends and patrons of the firm of Bengough Brothers. ${ }^{41}$ 
In the mid-I870s Thomas embarked upon his own career, although he was never far from the affairs of his family. At this time he became Oliver Mowat's private secretary and was a court reporter. In I879 he was involved in the publication of the Christian Helper and the Christian Reporter. ${ }^{42} \mathrm{He}$ was 'the literary manager' of the former periodical, which began on I 5 May I 877 as a Baptist monthly, and the secretary-treasurer of the Christian Helper Printing and Publishing Co. ${ }^{43}$ Under Thomas's editorship the Christian Helper became a weekly newspaper and claimed to be 'The only Religious Journal in Canada which furnishes Special Phonographic Reports, Sunday School Lesson Notes, and Illustrations of Public Persons and Institutions. ${ }^{44}$ The Christian Reporter was a Christian nondenominational journal, for which Thomas was the associate editor in I $88 \mathrm{I}$. In terms of publication neither periodical operated independently of the Bengoughs. ${ }^{45}$ Although the Christian Helper was published by its associated publishing company up to the end of 1880 , its address was that of the Grip office. The business manager of both the Christian Helper and its associated publishing company was Samuel J. Moore, who had formerly served as city editor of the Barrie Gazette. With Moore and Alexander Richardson, Thomas formed the partnership of Bengough, Moore \& Co. ${ }^{46}$ Located at 30 Adelaide St. West, this short-lived firm took over the publication of both the Christian Helper and the Christian Reporter for the first seven months of $\mathrm{I} 88 \mathrm{r}$.

In I 880 the Grip office was still located at the Imperial Buildings, but the printing plant of Bengough Bros. was located at 55 Front St. East. In May I88I the entire company moved to new headquarters adjacent to the Court House at 55 Adelaide St. East in 'commodious and elegant premises erected expressly for Grip. ${ }^{47}$ The following report describes the variety of work provided by Bengough Bros. in these new premises:

\footnotetext{
... We have a very complete job printing office, stocked with the best material and superintended by competent workmen; our Relief Plate Process department is also now in capital running order. We are therefore in a position to execute orders for letter-press and pictorial work of all kinds, as well as for lithography, wood engraving, etc., in a manner and at rates which we feel confident will prove satisfactory to all who favor us with their work. ${ }^{48}$
}

George's departure on 30 August I 88 I coincided with the dissolution of both Bengough Bros. and Bengough, Moore \& Co. Richardson retired from the latter firm on the same date, enabling Bengough, Moore, and Thomas to enter 'into co-partnership as general printers, publishers, and zincographers' under the name Bengough, Moore \& Bengough. ${ }^{49}$ Moore officially took over the duties of business manager of Grip in January 1882. 
Although in the next month the company offered to sell $\$ 30,000$ in public shares at $\$$ Io each from its capital stock of $\$ 50,000,{ }^{50}$ legal application had already been made by this time to form a new firm called the Grip Printing and Publishing Co. Bengough, Moore, and Thomas were among the directors of this new company. The two other directors were George Clarke and James Leckie Morrison. ${ }^{51}$ On 25 February 1882 a prospectus of the Grip Printing and Publishing Co. was issued to Grip subscribers. At the inaugural meeting of the board of directors on 7 March I882, Morrison was elected president and Moore secretary. By-laws regulating the affairs of the company were adopted, and arrangements were made to take over the business of Bengough, Moore and Bengough. By this latter date $\$ 28,000$ of the company's public stock had been subscribed. Bengough was appointed as Grip's editor with sole literary and artistic control of the paper. ${ }^{52}$

With this re-arrangement of corporate structure and new-found capital, the weekly circulation of Grip increased from 2,000 readers in I88I 'to between 7,000 and 10,000, with an average weekly increase of 100' in April I 883 . The paper boasted that it was 'perused by fully 50,000 readers every week. ${ }^{153}$ In January I 886 the company claimed to be 'the Largest Book and Job Printing House in Canada and Best Equipped for Commercial, Legal and Book Printing' with 'the most complete engraving department in the Dominion. ${ }^{54}$ In the 1870 s the Bengoughs had gone from lithography to wood engraving and back again to lithography as a means of graphic reproduction. ${ }^{55}$ In the early 188 os one of their employees, William Stuart, mastered zincography, a method of etching on zinc that combined 'the advantages of lithography and wood engraving, while being cheaper than either. ${ }^{56}$ The Grip Printing and Publishing Co. handled practically every facet of printing and publishing, from books and journals to miscellaneous items such as druggists' labels and envelopes, all to customer specification. One speciality was the manufacture of 'counter check books,' for which the company had the only machinery available in Canada. ${ }^{57}$

In later years Bengough was tempted to chronicle Grip's history because he wanted to convey the personal quirks of some of his regular contributors. The gallery of contributors included R.W. Phipps, Tom Boylan, Edward Edwards, Mrs. J.K. Lawson ('Hugh Airlie'), George Orran, and Fred Swire. These writers Bengough singled out as noteworthy, and indeed they were all colourful characters. According to Bengough, for example, the dress and deportment of Phipps suggested the countryman coming to town for the first time. Known for his 'lady-like' manuscripts, Phipps was such an egotist that he solemnly pronounced his contributions better than anything in Punch. ${ }^{58}$

From the perspective of the I980s, it must be admitted that Bengough's list of Grip writers is not especially memorable or impressive. Bengough, 
however, does omit several important Grip writers whose reputations have endured. For example, Charles G.D. Roberts' poem 'The Domesticated Brave' appeared in four instalments in October and November I $884 .{ }^{59}$ During his student days at the University of Toronto before he went to New York and edited Truth, Peter McArthur was a frequent contributor to Grip. He wrote columns with titles such as 'Croaks from Grip's Basket' and 'Crumbs from the High Table.' His first contribution, a series of seven jokes titled 'Jokelets,' appeared in January I 890 . One of the seven jokes, captioned 'No Effort Should Be Spared,' surely produced more groans than laughter from readers:

Doctor - I am afraid your husband is dying, madam.

Wife (wildly) - Oh, you must not let him die, doctor. He hasn't even written his will yet. ${ }^{60}$

The Canadian author that Grip lionized above all other literary contenders was Alexander McLachlan. Grip called him 'Canada's Acknowledged Poet-Laureate. ${ }^{\prime 61} \mathrm{He}$ contributed more than sixty pieces to Grip from I 5 May I 886 to 22 December I 888 , and he contributed another two poems on ro September i 892 and Io June r 893 .

It would be wrong to think that in promoting the cause of Canadian writing, Grip took itself too seriously. The magazine frequently satirized the idea of a national literature. In one article it gave advice to aspiring writers. One should be born outside the country in England or Scotland, be patriotic at all times, write in a formal, stilted style, discuss the state, need and progress of Canadian literature, work the 'mutual admiration racket,' and mention other native writers without necessarily reading any of their works. ${ }^{62}$ In another article Grip lamented the untimely death of Canada's 'famous' writer, Bardolph Balderdash. A few lines from his obituary notice convey the flavour of Grip's delicious satire:

His name was upon every tongue, and no book of selections, in prose or verse, from Canadian authors, was considered complete without large extracts from his works. His garret study was thronged with the good and great, and became a Mecca for the aspiring literary pilgrim. ${ }^{63}$

During the mid-I88os the Grip Printing and Publishing Co. undertook the publication of a wide variety of books and journals. The company's publication of books can be readily appreciated by a scrutiny of the printers' index to Canadiana, 1867-1900: Monographs. Serious works such as Mrs. Clarke's Cookery Book (1883) and Principal Grant's Inaugural Address Delivered at Queen's University, Kingston, on University Day, 
1885 (I 885 ) contrast sharply with Bengough's own Bunthorne Abroad: Or, The Lass That Loved a Pirate (I 883). Perhaps the company's most successful publication was the two volumes of Bengough's $A$ Caricature History of Canadian Politics (1 886). In his preface to the first volume, G.M. Grant wrote:

Grip is impartial, in a country where it is very hard to be impartial, and harder still to have your impartiality acknowledged.... He is scrupulously clean. He never sneers. In the best sense of the word, he is religious.... Grip's humour is his own. It has a flavor of the soil. It is neither English nor American. It is Canadian. ${ }^{64}$

Besides Grip, the Grip Printing and Publishing Co. at one time or another was the publisher of the Educational Journal, School Work and Play, the Grip-Sack, the Illustrated War News, Labor Advocate, and the Ontario Gazette. From I 880 to 1893 the company annually issued Grip's Comic Almanac, and in May I 887 monographs appeared in the series Grip's Own Library. In practically every issue of Grip during this period, one can also find advertisements for coloured engravings of political personalities and events.

Eleven employees of the Grip Printing and Publishing Co. appear on the Toronto tax assessment rolls in I883. Besides Bengough and Moore, the following individuals were company employees: George Crammond (ad agent), William Stuart (lithographer), R.R. Younger (bookkeeper), James S. Ellis (foreman), Thomas Taylor (printer), Henry Hunt (printer), Alexander Richardson (printer), John Moore (pressman), and James Bengough (printer). ${ }^{65}$ Unfortunately, for most of the years during which the Bengoughs were in business, the tax assessment rolls appear to list only major employees, and, in later years (I89I-92), when the company shared quarters with James Murray \& Co., it is not readily apparent where the listing of employees from one company begins and ends. ${ }^{66}$

Moore resigned as general manager in April I 886 and took up a similar position with James Murray \& Co. until at least I 89I.$^{67}$ At the Grip Printing and Publishing Co., he was succeeded by James V. Wright. Between March and July I 887 the manager of the publishing department was Richard T. Lancefield, who published a book in support of the single tax under the Grip imprint in I 888 and a year later became the editor of the Canadian Bibliographer and Library Record. ${ }^{68}$ In I 889 Henry Hough, who founded the Cobourg World in I864, took over Lancefield's job for at least several months. ${ }^{69}$ Also, in June of that year, Wright became president of the firm, and T.G. Wilson became general manager. Thomas Phillips 
Thompson, who had briefly served as the editor of Grip in I873, joined Bengough as associate editor in May i 890.

These changes in personnel are of some interest insofar as they tell us who worked for the Grip Printing and Publishing Co. and who had what responsibility. However, in terms of the evolution of the company itself and the termination of the involvement of the Bengough family in the company, the changes tell a larger story. On 6 August I 892, Bengough was dismissed as Grip's editor and was removed from the company's board of directors. He never regained control of the company although he briefly revived Grip in I 894 after it had ceased publication on I 5 July I 893 .

In the opinion of Hector Charlesworth, the renowned editor of Saturday Night, Grip lost its public appeal with the death of Macdonald in I89. ${ }^{70}$ Grip had built its reputation on Macdonald's foibles. In spite of the fact that Bengough had turned out wonderful cartoons of political figures such as Mowat, Mackenzie, and Edward Blake, Macdonald was Bengough's chief object of satire. Charlesworth also argues that the competition from rival magazines and Bengough's tendency to act as a propagandist also account for Grip's demise:

Grip died through outside competition. It could not match the finely produced comic weeklies of the United States, Puck, Judge and Life, or the exquisite finesse of Punch. Bengough, too, as the years went on, became more of a propagandist and less of a cartoonist. He lost ground in Canada, where new men of higher technical ability, like Sam Hunter, were coming to the fore, through trying to crowd too much verbal argument into his pictures. ${ }^{71}$

Charlesworth's explanation of Grip's demise is speculative, however, and must be modified in light of the recollections of Thomas Bengough. According to Thomas, there were financial mismanagement and personality conflicts within the Grip Printing and Publishing Co.

The formation of the Grip Printing and Publishing Co. in I882 strengthened the business substantially in its financial stability and potential for growth, but the formation also allowed for the possibility of outside interests to control what essentially had been a family business. In the company's annual returns for I887-88, the amount of capital stock was $\$ 100,000$ divided into I0,000 shares. Eighty-four people had shares in the company in I 887 and ninety-nine people in $1888 .^{72}$ Although Bengough and Thomas were directors of the company, together they owned only a small percentage of the shares. The board of directors consisted of five people, which meant that the two brothers could be out-voted on any issue. 
On 3 December 1883 the company negotiated with Frank Squire Wilson, the printer for the Ontario Legislature, to take over Wilson's contract with the Ontario government for a period of five years. Another firm had in fact made a lower tender. In order to secure the contract, the Grip Printing and Publishing Co. paid the firm $\$ 5,000$. The company believed that the deal would turn out to be a good one in the long run because 'a former contractor had cleared about $\$ 80,000$. from the contract - at least this was reported, and the story was pretty well verified by the fact that the contractor became a Bank Director. ${ }^{73}$ In anticipation of the increased work, the company moved to 26-28 Front St. West in I884 and expanded its staff and purchased more equipment. Unfortunately, the government contract proved to be a major loss. In March I 886 the company transferred the government contract to Warwick \& Sons. The latter firm purchased Grip's printing plant for the government work and rented the top flat of the Grip building until December I $888 .^{74}$ From I 886 to 1893 the building was also shared by James Murray \& Co. The major partners of James Murray \& Co. were James Murray and T.G. Wilson, both of whom also worked for the Grip Printing and Publishing Co. as printing foreman and bindery foreman respectively. "These two men called themselves the "honey bees" who made the honey,' Thomas recorded in bitter reminiscence,

and they arranged matters so that, by boring from the inside, they removed the members of the Grip Board, and Wilson came to the fore as the big boss. As a result of loss from the [government] contract, and general mismanagement, the Artistic Department was disposed of to Mr. [George] Howell, and large sections of the equipment were sold, and the Grip Company went out of business, with a total loss to J.W.B. and his brother, of their total investment. $^{75}$

Thomas's account is wrong on at least one point. The Grip Printing and Publishing Co. did not go out of business when Bengough was ousted from the board of directors and was dismissed as Grip's editor. A month after his dismissal the company moved 'to larger premises at $20 \mathrm{I}$ and 203 Yonge St. ${ }^{76}$ and engaged a variety of artists such as A.G. Racey, Buckton Nendick, and F. Wright. Without Bengough's humour and intimate knowledge of public affairs, Grip under Wilson's auspices 'lived at a poor dying rate ... with Cartoons lacking point and reading matter having no interest or punch or snap.' Subscriptions were lost by the 'dozens, hundreds, and even thousands. ${ }^{\prime 77}$ Such is Thomas's synopsis of Grip after his brother left the magazine. What is certain is that Grip was in trouble by March 1893 when George A. Howell was appointed business manager. Howell instituted a 'Publishers Department.' Its purpose was to tell 
our friends the subscribers, of the progress of the paper... [We] will ask them to assist us in increasing this progress, tell of how we will show our appreciation of their efforts in this direction, speak of our plans for the future, in short, talk 'business' to them which we hope will result to our mutual advantage. $^{78}$

The column repeated a series of offers to readers who could get farm journals and women's magazines practically free with a subscription to Grip. Although the ploy had been used before, this time it did not work. The magazine was put up for sale. A number of tenders were received on $3 \mathrm{I}$ May I 893. The two highest bids were acceptable to the board of directors, but in the end both tenders failed to secure the required capital. In a circular issued to subscribers the company stated:

Owing to the delay in ascertaining the bona fides of the security, the other offers have been withdrawn, and, under these circumstances, the Company has come to the decision to suspend the paper temporarily, while preparations are made for bringing it out in a new and improved form. In the interval the management of the paper will be thoroughly reorganized, and there is every reason to believe that when the paper reappears it will be a great improvement upon the Grip of former years. ${ }^{79}$

In August I 893 the Printer and Publisher announced that the Grip Printing and Publishing Co. was

still in business, all rumors to the contrary notwithstanding. Their engraving department is doing a large and rapidly increasing business, and they are increasing their facilities for doing this class of work. Half tone engraving on copper is also one of their strong points. The suspension of the comic paper leaves the firm free to give all their attention to their custom departments. ${ }^{80}$

In October 1892 Bengough became the cartoonist of the Montreal Star, ${ }^{81}$ but in January I 894 he was back at the editorial helm of a resurrected Grip. His business partner was Josiah Jones Bell, a journalist and former publisher of the Brockville Recorder. ${ }^{82}$ The name of their firm, the Phoenix Publishing Co., suggests that they believed that Grip would rise triumphantly from its own ashes. Although the first issue of the revived magazine looked similar in appearance to its former self, Bengough made it quite clear that with the exception of the subscription list and the magazine's name, his venture had no connection with the Grip Printing and Publishing Co. 'Grip's prime object in life will be fun, but not merely aimless frivolity,' Bengough told his readers. 
Grip will aspire to regain his old place in the affections of the Home, and to become before long the best epitome of Canadian literary and artistic talent, as well as the trusted ally of all who are working for the good of mankind in general and the glory of the Dominion of Canada in particular. ${ }^{83}$

The new Grip attempted to live up to its image as a forum for satire, literary endeavour, and political commentary. Bengough had not lost his touch. Perceptive, clever, and imaginative, his cartoons were matched by his comic writing in I 894. Indeed, there was plenty of talent in evidence in the revived magazine. One of the contributors, for example, was the young Stephen Leacock. ${ }^{84}$ Four pages of ads accompanied each issue, but they were not enough to sustain the magazine financially. In retrospect Thomas would blame the failure of Grip's revival on 'the lack of energetic management of Mr. Bell. ${ }^{85}$ Subscriptions never materialized as Bengough had hoped. In the last issue, which appeared on 29 December I894, readers were informed:

A large number of subscriptions to GRIP expire with the end of the year, a few are paid ahead, but, alas, many are in arrears. Accounts have recently been sent to all such, and we now beg to notify them that these accounts MUS T be paid forthwith. Neglect will entail unpleasantness. A word to the wise is sufficient. ${ }^{86}$

With the exception of George's involvement as manager of the Commercial Lithographing Co. in I 898-99, the demise of Grip marked the end of the contribution of the Bengough family to Canadian publishing and printing. Bengough continued his career as a cartoonist, writer, polemicist, and platform entertainer. He was the cartoonist for the Toronto Globe in I 896, ${ }^{87}$ lectured at the Imperial Institute in London in $\mathrm{r} 898$, served as an alderman in Toronto between 1906 and $1909,{ }^{88}$ went on a speaking tour in Australia and New Zealand in 1909, and was also a teacher of elocution at Knox College several years later. On his last Canadian tour, he gave sixty free lectures to high schools in addition to his regular speaking engagements. On 2 October 1923 , during a lecture, 'while drawing a series of cartoons on moral reform,' he fell from his chair and died. ${ }^{89}$ Thomas tried to memorialize his brother's achievements. Bengough, however, was forgotten for some thirty years after his death until his cartoons were used in Donald Creighton's John A. Macdonald: The Old Chieftain (I955). Professional historians, following in Creighton's footsteps, have often employed Bengough's cartoons and commentaries.

By December 1893 the Grip Printing and Publishing Co. concentrated exclusively on engraving and closed out its other departments. The 
company based its reputation on photo-engraving although it claimed expertise in other areas of engraving as well. The firm claimed possession of 'all the most important plant and machinery, including two 4,000 candlepower electric lamps,' which made them independent of the sun. ${ }^{90}$ In I90I the business changed hands and was re-incorporated as Grip Ltd. in January I902. ${ }^{91}$ George A. Howell who had managed the company in former years was re-engaged along with the old staff. ${ }^{92}$ One of the employees was the painter J.E.H. MacDonald who worked for the Grip Printing and Publishing Co. and its successor from I895 to I903. He rejoined Grip Ltd. in 1907 and became fast friends with several of his co-workers. They founded the Group of Seven. ${ }^{93}$ In 1926 Grip Ltd. amalgamated with the Rapid Electrotype Co. and became known as Rapid Grip Ltd. Another corporate re-structuring occurred in January I93 I when Batten Ltd. merged with Rapid Grip Ltd. to form Rapid Grip and Batten Ltd. The current successor to the latter firm is Bomac Batten Ltd. ${ }^{94}$ The long link of succession from Bomac Batten to Grip is consequently tenuous. Interestingly enough, when the Vice-President of Bomac Batten was asked in 1975 about the copyright in Grip and the work of Bengough, he laid claim to such copyright by virtue of Bomac Batten's corporate ties to the Grip Printing and Publishing Co. He admitted, however, that Bomac Batten's attempt through legal channels to secure such copyright had failed. ${ }^{95}$

NOTES

I Dora Hood, The Side Door: Twenty-Six Years in My Book Room (Toronto: Ryerson, I958), p. 7. Two of Dora Hood's antiquarian catalogues (no. 23 (I938) and no. 24 (I939)/ can be found in the papers of J.W. Bengough at McMaster University, Hamilton, Ont. (hereafter в P). The papers were deposited by Thomas Bengough in I 939 and were the first archival collection that McMaster acquired.

2 Obituary of Thomas Bengough, Canadian Baptist 9I, no. 2 (I 5 Jan. I945): Io; Elizabeth Hulse, A Dictionary of Toronto Printers, Booksellers and the Allied Trades, 1798-1900 (Toronto: Anson-Cartwright Editions, I982), p. 20.

3 Information on Bengough's social and political campaigns has been obtained from the following sources: Stanley Paul Kutcher, 'John Wilson Bengough: Artist of Righteousness' (M.A. thesis, McMaster University, I975); Dennis Edward Blake, 'J.W. Bengough and Grip: The Canadian Editorial Cartoon Comes of Age' (M.A. thesis, Wilfrid Laurier University, I985); and Ramsay Cook, The Regenerators: Social Criticism in Late Victorian English Canada (Toronto: University of Toronto Press, 1985), chapter 8 .

4 'The Pleasantries of Public Life' was the title of Bengough's first chalk-talk, which he gave on 20 March I 874 under the auspices of the Mechanics' Institute at the Old Music Hall in Toronto. His presentation was such a success on that occasion that his sketches of the evening were auctioned off immediately after the talk, 
fetching a total price of $\$ 45.00$. See J.W. Bengough, Bengough's Chalk-Talks: A Series of Platform Addresses on Various Topics, with Reproductions of the Impromptu Drawings with Which They Were Illustrated (Toronto: Musson, I922), pp. I3-2I.

5 National Archives of Canada microfilm: Ontario Census for I 86 I, Enumeration District No. I of the Centre Ward of the Town of Whitby, No. [i.e. p.] 6; and Ontario Census for I871, District No. 48, South Ontario, Sub-District, Centre Ward of the Town of Whitby, p. 78. In the I86I census a girl Joanah /transcription uncertain), aged I 3 , is listed, but she is not listed in the I87 I census. In the $187 \mathrm{I}$ census the ages given for family members are as follows: John (the father) $5 \mathrm{I}$, Margaret (the mother, née Wilson) 5I, George 24, John Wilson 20, Thomas I 8, May I4, James Io, and William 8. In the I86I census George's occupation is listed as printer, but in the $\mathrm{I} 87 \mathrm{I}$ census he is listed as a merchant (he operated a bookstore in Whitby). Also, in the $187 \mathrm{I}$ census, Bengough's occupation is said to be printer, and Thomas is listed as a clerk.

6 Thomas Bengough, 'Life and Work of J.W. Bengough, Canada's Cartoonist,' p. I, address given to the Bell Club in Toronto on 30 Jan. 1937, в P.

7 Henry James Morgan, ed., The Canadian Men and Women of the Time, $2 \mathrm{~d}$ ed. (Toronto: William Briggs, I9I 2), p. 91. For Bengough's attitude toward religion, see Kutcher, 'John Wilson Bengough,' pp. 2 I-32 and chapter viI, 'Nation, Nature, and the Two Theologies.'

8 Bengough's Chalk-Talks, p. 4.

9 Thomas Bengough, 'Life and Work of J.W. Bengough,' p. 3.

Io Ham 'afterwards became famous as a showman of the C.P.R. and chaperoned all the Dukes, Earls and Bigwigs who toured Canada by that railway.' See Thomas Bengough, 'Life and Work of J.W. Bengough,' p. 4; and George H. Ham, Reminiscences of a Raconteur between the '40s and '20s (Toronto: Musson, 1920), p. 3 .

I I Thomas Bengough, 'Life and Work of J.W. Bengough,' p. 4.

I2 Bengough's Chalk-Talks, pp. 6-7, 9.

I3 Ibid., p. 8.

I4 Grip 26, no. 26 (3 July I 886). I have not given pagination in citations referring to Grip because prior to 1887 issues lack page numbers.

I 5 Peter Desbarats and Terry Mosher, The Hecklers: A History of Canadian Political Cartooning and a Cartoonists' History of Canada (Toronto: McClelland and Stewart, 1979l, pp. 42-44. See also Desbarats, The Canadian Illustrated News: A Commemorative Portfolio (Toronto and Montreal: McClelland and Stewart, I970), pp. 4-7; Jim Burant, 'The Visual World in the Victorian Age,' Archivaria, no. I9 (Winter 1984-85): I I 8-20; and George L. Parker, The Beginnings of the Book Trade in Canada (Toronto: University of Toronto Press, I985), pp. I53-54.

I6 Bengough's Chalk-Talks, p. I I. 
I7 Bengough's Chalk-Talks, pp. I I-I2. Bengough's first caricature of Beaty is apparently not extant. However, when the Conservatives were in complete disarray as a result of the Pacific Scandal and faced a general election in I874, Bengough used the occasion in Grip to portray Beaty as the chief mourner at the funeral of the party. Bengough borrowed Shakespeare's lamentation 'Of comfort no man speak; let's talk of graves and worms and epitaphs!' as a caption. See Grip I, no. 23 (I Nov. I 873). For biographical information on Beaty, see Hulse, Dictionary, pp. I6-I7.

I 8 There was also a price hike on 9 Jan. I 886 when an issue sold for ro cents and a year's subscription for $\$ 3$. The original subscription rates were reinstated on $\mathrm{I}_{4}$ Aug. I 886 .

I9 Thomas Bengough, 'Life and Work of J.W. Bengough,' p. I I.

20 Charles Dickens, Barnaby Rudge: A Tale of the Riots of 'Eighty (Oxford: Oxford University Press, I982), p. 34I. See also Grip I, no. I (24 May I 873) and 2, no. 2 (I7 Jan. I 874). Bengough was a leading member of the Toronto branch of the Dickens Fellowship and acted in several of its plays. He wrote 'Bardell vs. Pickwick,' a theatrical adaptation of part of the Pickwick Papers. The play was staged by the Dickens Fellowship in Toronto, earning \$ I 200 in a week, and the proceeds were donated to Toronto's Sick Children's Hospital for a memorial 'Bengough' cot. Various manuscripts of the play are extant in B P. It was published in James Edmund Jones, comp., Scenes from Dickens: Trials, Sketches, and Plays (Toronto: McClelland \& Stewart, I923l, pp. 7-78.

2 I Thompson's articles from the Mail were published under the title The Political Experiences of Jimuel Briggs, D.B. (Toronto: Flint, Morton \& Co., I873). For information on Thompson, see Cook, The Regenerators, chapter 9.

22 "The Story of "Grip" ' in Grip Almanac 1881 (Toronto: Bengough Bros., I 881), p. 70; Bengough, 'Recollections of a Cartoonist II,' Westminster I4, no. 3 (March I 909): I $83-84$.

23 On Grip's editorial policy, see Grip I, no. I (24 May I 873); I, no. 7 (I 2 July I 873 ); I, no. 9 (26 July I873); and I, no. I6 (I3 Sept. I873).

24 Grip 2I, no. 2 (23 Jan. I883).

25 P.B. Waite, 'Sir Oliver Mowat's Canada: Reflections on an Un-Victorian Society,' in D. Swainson, ed., Oliver Mowat's Ontario (Toronto: Macmillan, I972), p. 29; Hector Charlesworth, The Canadian Scene: Sketches, Political and Historical (Toronto: Macmillan, I927), p. I 28.

26 Bengough, 'Recollections of a Cartoonist III,' Westminster I4, no. 4 (April I909): $250,252$.

27 Bengough's Chalk-Talks, p. I3.

28 See Charles Pelham Mulvany, Toronto, Past and Present: A Handbook of the City (Toronto: W.E. Caiger, I 884), p. 202. 'This plucky and impartial cartoon paper had its inception in the Pacific Scandal year when it floated into fame by a happy 
knack of catching the humorous aspects of Canadian politics, with a specially felicitous presentation of the well-known features half lugubrious, half comic, of Sir John, then undergoing penance for his misdeeds.'

29 Grip I, no. I2 (16 Aug. I 873).

30 Thomas Bengough, 'Life and Work of J.W. Bengough,' p. Io. See also P.B. Waite, Macdonald: His Life and Work (Toronto: McGraw-Hill Ryerson, I975), pp. I24-26.

3 I "The Story of "Grip",' p. 70.

32 Bengough, The Grip Cartoons: Vols. I \& II. May, 1873, to May, 1874 (Toronto: Rogers \& Larminie, I875), introductory note. Grip was published every Saturday. The oath 'Never say die' is frequently uttered by Grip in Dickens' Barnaby Rudge. Grip I, no. I2 (I6 Aug. I 873).

34 Grip 3, no. I (30 May I874).

35 RG 55 (Partnerships), York County, no. I356 CP, 8 Jan. I 877, Archives of Ontario. Cited by Hulse, Dictionary, pp. 20-2 I but with the registration date Io Jan. 1877 . In I 875-76 George was also involved in the firm Riel \& Co., but I have been unable to find any information on the affairs of this company beyond the brief entry in Hulse's Dictionary (p. 2 I 4 ).

36 Grip 8, no. 24 (5 May I877).

37 Grip 5, no. I (29 May 1875) and 8, no. I (25 Nov. I 876).

38 See the wrapper of The Decline $\Theta$ Folly of Keewatin; Or, The Free-Trade Redskins (Toronto: Grip Office, I 876).

39 Grip II, no. I3 (I7 Aug. I878).

40 The real estate agency called Bengough \& Mussen amalgamated with Bengough Bros. in I 878. See Grip 9, no. 7 (7 July I 877) and I I, no. 3 (22 June I 878).

4I Grip I7, no. I6 (3 Sept. I88I). Although George resigned as Grip's business manager, he was actively involved in other business ventures. In the $\mathrm{r} 88 \mathrm{os}$, for example, he was the general manager of Bengough's Shorthand and Business Institute (also called Bengough Brothers' Employment Bureau and other similar names) and an agent for the Remington Type-Writer. For further biographical details, see Hulse, Dictionary, p. 20.

42 In I 880 Thomas also began Bengough's Shorthand and Business Institute and edited the monthly magazine the Canadian Illustrated Shorthand Writer (published by Bengough Bros. and illustrated by Bengough). His sister May acted as the superintendent of the typewriting department.

43 See the Christian Helper 3, no. I9 (I 3 Dec. I 879): I 85; and Ontario Gazette I2, no. 43 (25 Oct. I 879$): 2$.

44 Christian Helper 3, no. I9 (I3 Dec. I879): I85.

45 According to Hulse's Dictionary (p. 2 I), Bengough Bros. was the publisher of the Christian Reporter and the printer of the Christian Helper.

46 R G 55 (Partnerships), York Country, 2396 CP, I 4 May I 88 I, Archives of Ontario. Thomas apparently formed another partnership in the I880s known as Bengough \& Brooks. This latter company undertook the publication of New Canadian 
Commercial Arithmetic (r 889) by Clark Moses, R.C. Cheswright, Charles H. Brooks, and Thomas. I have been unable to find any other information on this company.

47 Grip I6, no. 25 (7 May i 88 I).

48 'Our New Premises,' Grip I7, no. I (2 I May I88 I).

49 'Partnership Notices,' Grip I7, no. I6 (3 Sept. I88I). See also R g 55 (Partnerships), York County, no. 2459 CP, 3I Aug. I86I, Archives of Ontario.

50 'To Our Subscribers,' Grip I 8, no. I5 (25 Feb. I882).

5 I Ontario Gazette 25 (I882): 95, I94.

52 Grip I8, no. I6 (4 March I882) and no. I7 (I I March I882).

53 Grip 20, no. 2 I (28 April I 883).

54 Grip 26, no. I (9 Jan. I 886).

55 'Grip to His Patrons,' Grip 3, no. 3 (22 Aug. I 874).

56 Bengough's Chalk-Talks, pp. I3-I4. See also Bengough, 'Recollections of a Cartoonist II,' pp. I86, I88. According to Bengough, zincography was eclipsed in Toronto by the art of photo-engraving. In Bengough's account, Stuart is misspelled as Stewart, and he is said to have been hired in the late r88os. For biographical information on Stuart, see Hulse, Dictionary, p. 248.

57 The Grip Printing and Publishing Co. undertook the manufacture of a variety of cheque books. On behalf of J.R. Carter who had patented 'The Paragon Counter Check Book,' the company brought legal action against Harmon Benjamin Butterfield who had infringed the patent. See Ontario Appeal Reports i I (I 885): I45-55 and Supreme Court Reports I I (I 886): 29I-99. Both Morrison and Moore were involved in Carter \& Co., which continued the cheque book business of the Grip Printing and Publishing Co. See Hulse, Dictionary, pp. 52-53 and The Story of Moore - into the 2nd Century ([Toronto: Moore Corporation, I982]).

58 Bengough, 'Recollections of a Cartoonist II,' pp. I 88-89, and 'Recollections of a Cartoonist III,' pp. 249-50.

59 Grip 23, no. I 5 (I I Oct. I 884); no. I6 (I 8 Oct. I 884); no. I7 (25 Oct. I 884); and no. I 8 (I Nov. I884).

60 Grip 34, no. I (4 Jan. I 890): 7.

6 I 'Important Literary Announcement. Alexander M'Lachlan, Canada's Acknowledged Poet-Laureate, Engaged as a Regular Contributor to "Grip", ' Grip 26, no. I 8 (8 May I886).

62 'How to Become a Native Canadian Litterateur,' Grip 32, no. I4 (6 April I889): $2 \mathrm{I} 3$.

63 'A Successful Canadian Author,' Grip 33, no. 9 (3 I Aug. I 889): I36.

64 Grant, preface to Bengough, A Caricature History of Canadian Politics. Events from the Union of 1841, as Illustrated by Cartoons from 'Grip' and Various Other Sources (Toronto: Grip Printing and Publishing Co., I 886), I, p. 8. An abridgment of this edition with an introduction by Doug Fetherling was published in 1974 by Peter Martin Associates Ltd. 
65 City of Toronto Tax Assessment Roll for the Ward of St. James, part 2, I883, Gs6I96, Archives of Ontario. (Assessment rolls hereafter cited as C TAR, followed by the year and $\mathrm{G} S$ number.)

66 George and Bengough are listed as the only employees of Bengough Bros. in 1877, for example. In 1878 four employees are listed on the assessment roll: George, Bengough, Edward A. Poot (assistant), and John C. Mussen (insurance agent). See CTAR, I877, Gs-6I75, and I878, Gs-6I80. For I 892 three people besides Bengough are listed as employees of the Grip Printing and Publishing Co.: Thomas G. Wilson (manager), C.F. Kinsey (engineer), and William W. Doyle (bookkeeper). Four people are listed as employees of James Murray \& Co. in I 892: Murray (printer), Wilson (bookbinder), Morrison (bookbinder), and James V. Wright (bookbinder). These four employees of James Murray \& Co. were all associated with the Grip Printing and Publishing Co., however. See CTAR, I892, Gs-6245.

67 Grip 26, no. I7 (Io April I886); CTAR, I89I, Gs-6234.

68 Gordon Roper, 'The Canadian Bibliographer and Library Record and Its Editor,' Papers of the Bibliographical Society of Canada 6 (1967): 27-31. Lancefield's book is entitled Why I Joined the New Crusade: A Plea for the Placing of Taxes on Land Values.

69 For further information on Hough, see Hulse, Dictionary, p. I26.

70 Although Bengough criticized Macdonald severely in the pages of Grip, he paid Macdonald high tribute on Macdonald's death. See Bengough's poem, 'Sir John A Macdonald,' Grip 36, no. 24 (I3 June I89I): 374; and Bengough, Motley: Verses Grave and Gay (Montreal: William Briggs, r 895), p. 5 I.

7 I Charlesworth, The Canadian Scene: Sketches, Political and Historical (Toronto: Macmillan, I927), p. I29.

72 The other three directors in I 887-88 were Wright, Morrison, and Moore. The amount of stock which each director owned in these two years is as follows: Bengough $\$ 360$ in both years; Thomas $\$ 360$ in 1887 and $\$ 2,610$ in I 888 ; Wright $\$ 13,440$ in I 887 and $\$ 9,650$ in I 888; Morrison $\$ 420$ in both years; and Moore $\$ 530$ in both years. RG 8 (Department of the Provincial Secretary), Series I-I-D, \#946 (I 888) and \# I339 (I 889), Archives of Ontario. The annual returns for other years are not extant.

73 Thomas Bengough, 'Memoranda re File of "Grip," with Suggestions as to Binding,' 9 March I939, p. 5, B P. In Thomas's account the Grip Printing and Publishing Co. was awarded the contract with the Ontario government in 1886.

74 Copy of an Order in Council and of Other Documents Relating to the Assignment of the Contract for Government Printing from the Grip Printing and Publishing Company to Messrs. Warwick \& Sons no. 57, Sessional Papers (I 886), Archives of Ontario. The estimate of the cost of the printing plant was $\$ 20,000$.

75 Thomas Bengough, 'Memoranda re File of "Grip," with Suggestions as to Binding,' p. 5 .

76 'Craft Notes,' Printer and Publisher, I (Aug. I 892): Io. 
77 Thomas Bengough, 'Memoranda re File of "Grip," with Suggestions as to Binding,' p. 6 .

78 Grip 40, no. Io (I I March I893): I48.

79 To Our Subscribers, circular issued by the Grip Printing and Publishing Co., I 8 July I 893. Copy located in R G 8 (Department of the Provincial Secretary), Series II-D, \# 358I (I 893), Archives of Ontario.

80 Printer and Publisher 2, no. 8 (Aug. 1893): I 5. After I 890 the Grip Printing and Publishing Co. specialized in engraving and abandoned other areas of printing and book-making.

8I Printer and Publisher, I (Oct. I892): I2.

82 RG 55 (Partnerships), York County, I055 C PE, Io July 1894, Archives of Ontario.

83 Grip 42, no. I (4 Jan. I 894): 2.

84 Leacock, 'А B C or, the Human Element in Mathematics,' Grip 4I, no. 20 /I9 May I 894): I 55-56 and 4I, no. 2I (26 May I 894): I63-64; and 'That Ridiculous War in the East,' Grip 42, no. I4 (6 Oct. I894): I07. The former comic sketch in this first publication has never been recorded in any of the bibliographies of Leacock.

85 Thomas Bengough, 'Memoranda re File of "Grip," with Suggestions as to Binding,' p. 6.

86 Grip 42, no. 26 (29 Dec. I 894): iii, following 208.

87 See Jean Garratt, 'A Bibliography of the Cartoons Drawn by Mr. John Wilson Bengough for the Toronto Daily Globe, for the Years I 896, and Also His Verses, Magazine Articles, etc.,' ts., I 2 pp., I932, Faculty of Library and Information Science, University of Toronto (copy also available from the National Library of Canada); Cartoons of the Campaign (Toronto: The Poole Publishing Co., 1900).

88 Stanley Paul Kutcher, 'T.W. Bengough and the Millenium in Hogtown: A Study of Motivation in Urban Reform,' Urban History Review 5, no. 2 (I976): 30-49.

89 Thomas Bengough, 'Life and Work of J.W. Bengough,' p. 24.

90 'Trade Notices,' Printer and Publisher 2, no. 2 (Dec. I983): I2. See also 'The Art of Illustrating,' Printer and Publisher, 3 (Oct. I 894): Io-I 2.

9I RG 8 (Department of the Provincial Secretary), Series I-I-D, \#3I IO (I9O2), Archives of Ontario. I am grateful to Elizabeth Hulse who has allowed me to read her unpublished paper 'The Business of Illustrating in Late Nineteenth-Century Toronto.' Her paper contains a section on the Grip Printing and Publishing Co. relating to the company's re-incorporation in I902.

92 Printer and Publisher, ro (Dec. 1901): 19.

93 J. Russell Harper, Painting in Canada: A History (Toronto: University of Toronto Press, I966), pp. 269, 272.

94 'Birth of Engraving Industry,' Canadian Printer and Publisher 51, no. 6 (June 1942): 76,78 .

95 Bomac Batten Ltd. (D.R. Keedwell) to Mills Memorial Library, McMaster University (Susan Bellingham), 2 I April I975, master file, в Р. 


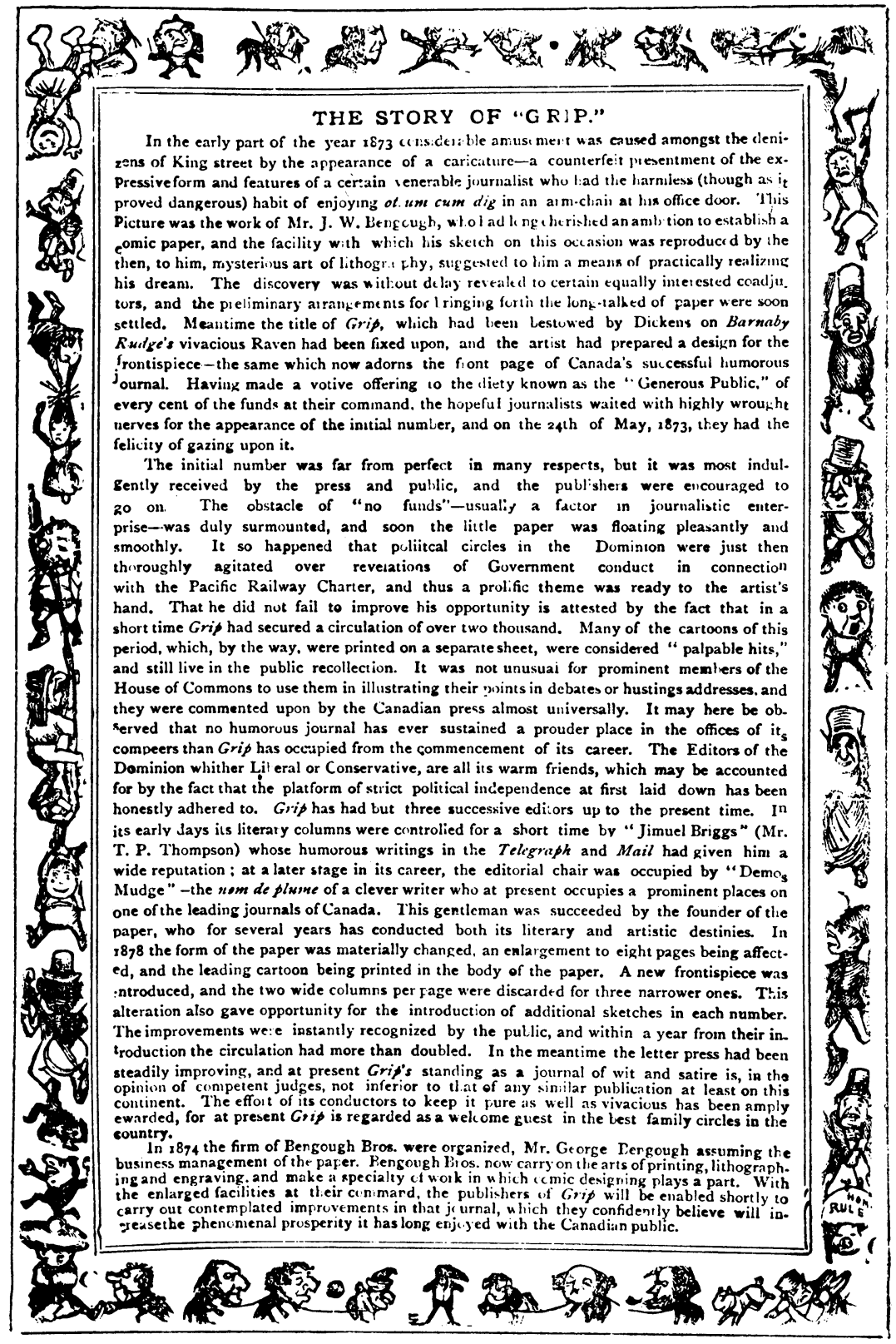

From Grip's Almanac 1881 (Toronto: Bengough Bros., I 88I), p. 70. 
IIII $\triangle N D$ WORK OF J. W. BENGOUGH, CANADA'S CARTOONIST

-by his brother, [addaces thell Club-ovscown

Thomas Bengough

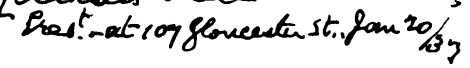

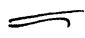

My Urother was before the Canadien public for practically half a century, and as he was an attive participant in many of the stirring events of the country during that period any brief sketch of his 11 fo and work must be rather unsatisfactory. My endeavor will be to touch only the high spots, and let the exhibition of his actual cartoon and 11terary work speak for itselr.

Toron to was his native c1ty, but at an early age my father, who was an cexpert oabinet maker and stalr builder, moved to Whitby to asist in the erection of the magnificant residence built by Sheriff Reynolds, and known as Trafalgar Castle, now oocupied a Ladied College.

While in his early toens in whitby he developed a fondness for the pencil which was recognised by his family and obool mates, and even by that formidable personege, the schoolmaster - a tall one-armed muscular individual who used a heary obony ruler to whack our fingers, and who studied law during school hours, using monitors to assist him in discipline, and who afterwards became a local judge. One Christmas dey this pedagog greatly surprised our family by stopping in front of jur house and leaving for my brother a beautiful box of paints. Simple as was this kindly

The first page of Thomas Bengough's typescript 'The Life and Work of J.W. Bengough, Canada's Cartoonist,' given as a speech to the Bell Club on 30 Jan. I937. 


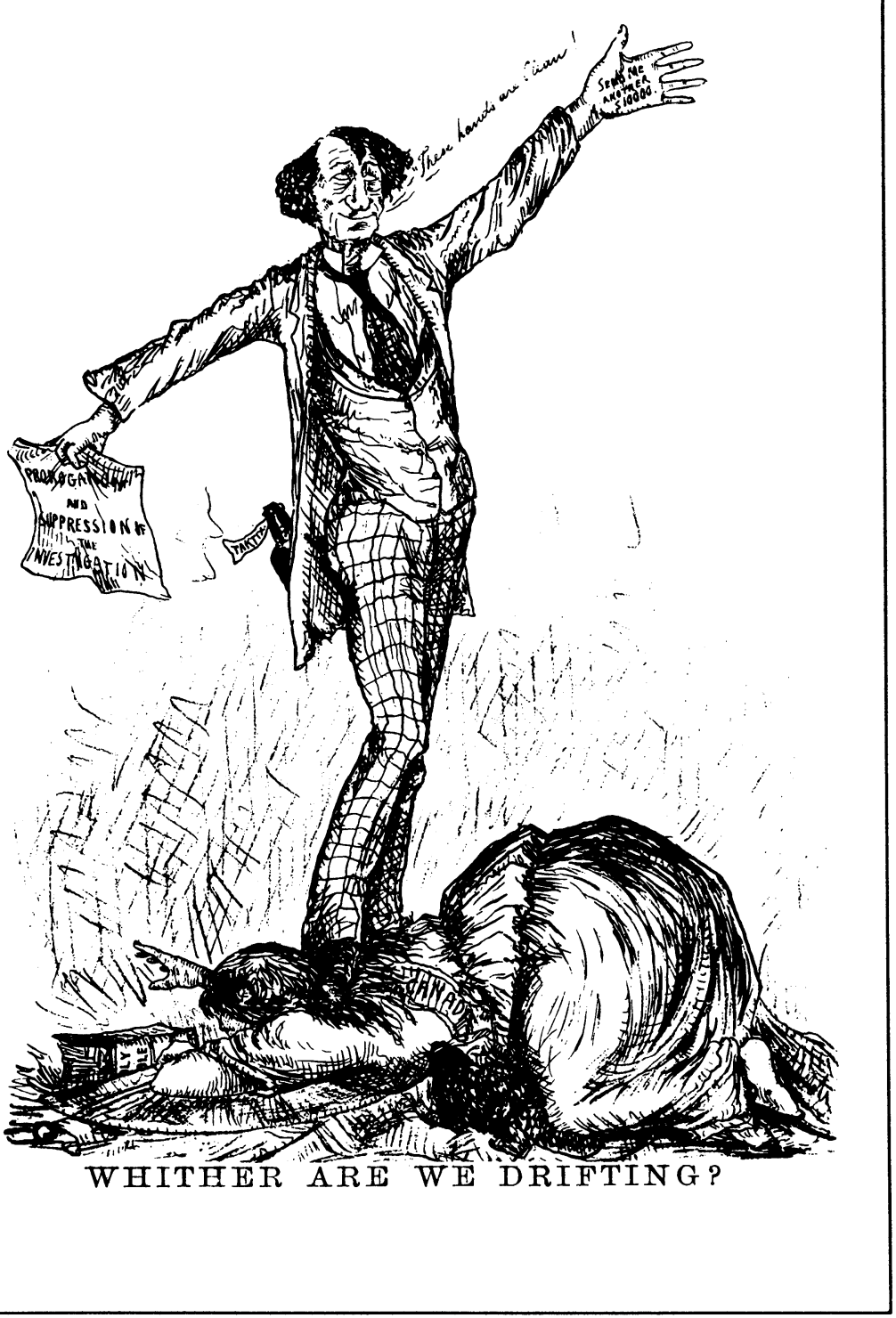

J.W. Bengough's cartoon 'Whither Are We Drifting,' satirizing Macdonald's involvement in the Pacific Scandal. From Grip I, no. I2 (I6 Aug. I873). 


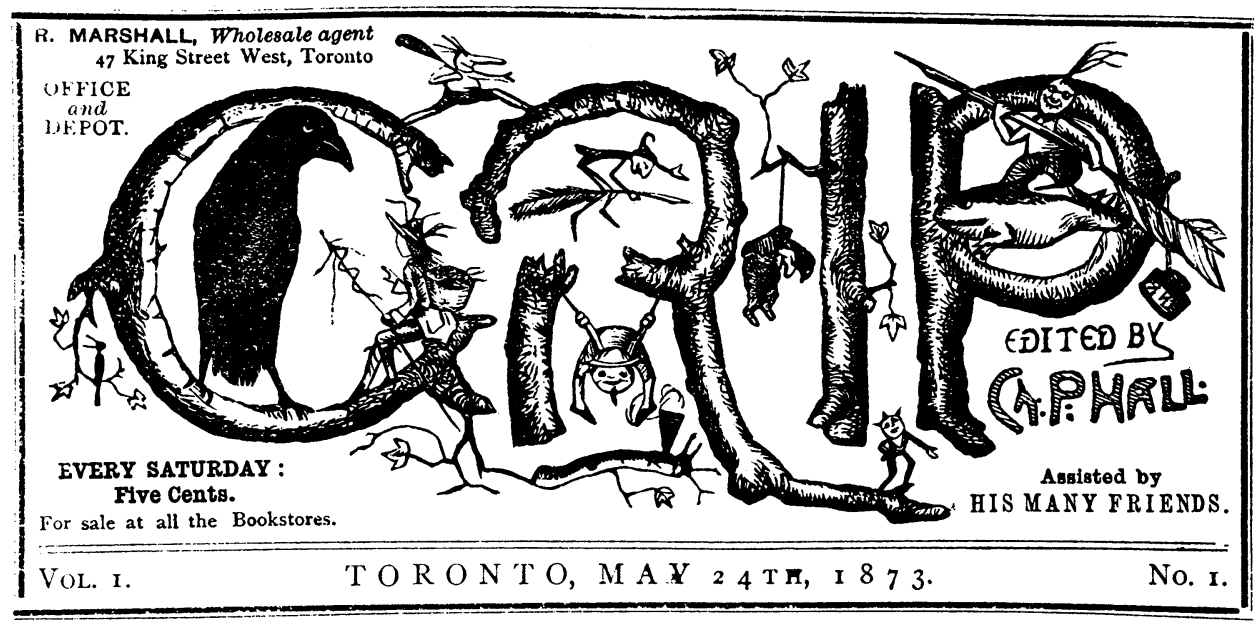

Grip's earliest masthead.

Illustrations courtesy of the William Ready Division of Archives and Research Collections, Mills Memorial Library, McMaster University. 